\title{
The Compliance of Methods of Implementation of IFRS: Study of the Impact on the Relevance of Accounting Information
}

\author{
Mohamed Rachid Ouezzani \\ Departement of Management, \\ National School Of trade and Management of Tangier,Morocco \\ Youssef Alami \\ Departement of Management \\ National School Of trade and Management of Tangier, Morocco
}

Received: June 28, 2014 Accepted: Oct. 4, $2014 \quad$ Published: December 1, 2014

doi:10.5296/ajfa.v6i2.5884 URL: http://dx.doi.org/10.5296/ajfa.v6i2.5884

\begin{abstract}
During the last two decades, many countries have chosen to implement the IFRS for at least one category of firms. According to Zeef and Nobes (2010), the implementation of IFRS can be classified into four methods. Thus, countries as Israel and South Africa have adopted the method "implementation process", others as Canada, Australia and the European Union have opted for the method called "Standard by Standard" while that Switzerland applies the "optional" method; China has chosen the "Not Fully converged" method. The analysis of these methods of implementation of IFRS demonstrates that these latter differ in terms of degree of compliance with the IFRS as issued by the IASB. This difference of compliance with the IFRS led us to wonder if it affects the quality of accounting information through its qualitative characteristic the "relevance".

To answer this question, we use an empirical model that we apply to a sample of listed companies from six countries opting for different methods of implementation of IFRS. The significant results found demonstrates that the compliance of methods of implementation of IFRS influences positively the relevance of accounting information and that this relevance is better for the listed companies of countries which have chosen a compliant method of implementation with the IFRS as issued by the IASB. These results complement the previous studies on the relevance of accounting information following the transition to IFRS and give
\end{abstract}


new significant proves on the impact of IFRS on the relevance of accounting information.

Keywords: IFRS, Implementation, Method, Compliance, Impact 


\section{Introduction}

The number of countries that have adopted for the IFRS is important. According to the survey of the IFRS Foundation, over 115 countries require or permit the application of IFRS for at least one category of firms. The number of these countries increases every year.

The European Union has been a pioneer in this domain with its adoption of the regulation 1606/2002 making mandatory the application of IFRS as adopted by the Union for the publication of consolidated financial statements of listed companies. The adoption of this regulation by the European Union was a solution to several problems of harmonization. Indeed, this union of countries includes constantly new countries adopting divergent national accounting standards. Although several regulations have been adopted by the European Union in the past, the accounting harmonization between the countries constituting this Union remained inefficient. The implementation of IFRS by the European Union was an ideal solution for this problem of accounting harmonization.

Following this decision of the European Union, several other countries have chosen to implement the IFRS. Some of these countries have started the process of implementation early while others are until now in the phase of study of project of implementation of IFRS. In fact, the introduction of IFRS requires a certain preparation and the establishment of a strategy of implementation. Thus, after the studies established by the countries wishing to implement the IFRS, these latter have opted for the suitable methods of implementation.

Several factors may explain the choice of the method of implementation of IFRS by a country. In fact the countries that entirely trust the international standard setter have opted for an advanced method of implementation named by Zeef and Nobes "due process" or have chosen the sub-method "IFRS as issued by the IASB"; others countries wishing to keep some control over standards applied by their companies have opted for the sub-method "fully convergence with IFRS" or the sub-method "IFRS with deletions"; countries wishing to give their firms the choice between two or more repositories have opted for the "optional" implementation; those wanting to conserve certain accounting standards have opted for the method "Not fully converged".

According to their compliance with the IFRS as issued by the IASB, these methods have been classified by Zeef and Nobes (2010) into 3 categories: The first category includes the methods that are "compliant", the second contains those "Possibly compliant" and the last one the methods "Unlikely compliant". This classification has prompted us to ask the following question: Is that the compliance of methods of implementation of IFRS with the IFRS issued by the IASB influences the relevance of accounting information?

To answer this question, we have examined the various methods of implementation of IFRS enunciated by Zeef and Nobes $(2008,2010)$ that we introduce in the first section accompanied by a review of literature of studies on the relevance of accounting information. Through this literature review, we have examined the different models used by the previous studies and have chosen the model that provides the best results in terms of significance. Thus, we have opted for the model of Ohlson (1995). Next, we have formulated the research 
hypotheses that we explain in the third section. In the fourth section we present the methodology as well as the sample selected. This later is constituted by companies listed on the stock market of six countries that have chosen different methods of implementation of IFRS. The significant results found that we report in the last section shows that the compliance of methods of implementation of IFRS influences- the relevance of accounting information. Also, they demonstrate that the relevance of accounting information is better in countries opting for compliant methods of implementation of IFRS with the IFRS issued by the IASB.

\section{Literature Review}

\subsection{Methods of implementation of IFRS}

The objective of the IASB is to make of IFRS an international accounting and financial standards. This is practically realized as enunciated by Gelard Gilbert. Indeed, this former member of the IASB made this statement on the basis of results of a study published by the IFRS Foundation. Based on the declarations of accounting standards authorities of 122 countries, this study has been established under the direction of Pacter (2014). It shows that the IFRS are today 'mandatory or widely used in more than 115 countries around the world.

According to the results found, from 122 countries, 101 require the use of IFRS for all or almost all domestic public interest entities (listed companies and financial institutions). Some countries, such as Australia, New Zealand and Hong Kong have adopted the IFRS as national standards. Two additional countries, Indonesia and Thailand, are in the process of adoption of IFRS. In addition to 101 countries, 10 countries including India, Japan, Switzerland and Singapore allow but not require the use of IFRS. Saudi Arabia and Uzbekistan require the IFRS only for the financial institutions.

In terms of number of companies adopting the IFRS, it is very difficult to get statistics. In addition to the 8,000 listed companies of Europe and the many foreign companies listed on the U.S. market that use the IFRS, the other entities which are unlisted and who have also adopted the IFRS make this operation difficult to establish. In fact, it requires making a detailed analysis by country.

In terms of companies concerned by the implementation of IFRS, most of countries that have required the IFRS, have made this requirement for the listed companies (excluding some financial institutions). Also, over $90 \%$ of the 101 countries that require the IFRS for listed companies require or permit these standards for most unlisted companies.

Concerning the IFRS for SMEs, the analysis of the report published by the IFRS Foundation reveals that 57 out of the 122 countries require or permit the norm IFRS for SMEs and 16 other countries are currently considering this option.

Also, the content analysis of report of the IFRS foundation shows that a large part of countries that have adopted the IFRS, have made very few changes to the text produced by the IASB. These changes are often considered temporary, as is the case in Europe concerning the IAS 39 underlined by the former member of the IASB Gilbert Gelard. In addition, the 
report of the IFRS foundation stipulates that some countries or regions have differed the dates of application of certain standards, in particular the recent IFRS 10, IFRS 11 and the IFRS 12.

In terms of methods of implementation of IFRS, Zeef and Nobes (2010) have established a classification of these methods for listed companies and have retained four methods of implementation. Thus, according to these authors the implementation of IFRS conducted in South Africa and Israel is an implementation "due process". It is the most advanced level of implementation and the most fairly close to IFRS issued by the IASB. By this method, the standards published by the process are automatically adopted by the country and applied by the firms concerned.

The second method of implementation of IFRS is called "Standard by Standard". This latter is divided into 3 sub-methods: The first one is called "IFRS as Issued by the IASB". It is considered as conform to IFRS issued by the IASB and consists in the adoption of IFRS published by the International normalizer after an automatic passage through the regulation. The only example given by the authors is the Canada. The second Sub-Method is called "Fully converged with IFRS". It is adopted in Australia, New Zealand and Honk Kong and consists on making a complete convergence of national standards with IFRS. The third sub -method called “As Issued by the IASB with deletions" consists on the application of standards adopted locally. It is considered by Zeef and Nobes as possibly conform to IFRS Issued by the IASB.

The third method of implementation of IFRS is adopted in Switzerland and named "optional" method. It aims to provide to the companies of the country the option to adopt IFRS or to choose another accounting referential. As for the sub-method "IFRS as Issued by the IASB with deletions", this method is considered as possibly compliant with the IFRS Issued by the IASB.

The fourth method of implementation of IFRS is called "Not Fully converged". It is considered as Unlikely with the IFRS Issued by the IASB. Indeed, trough this method, the normalizer leaves intact some standards. China is an example of countries adopting this method.

In terms of dates of implementation of IFRS, this later differs. For countries as South Africa, Israel and the E.U., the IFRS must be applied by the concerned companies the $1^{\text {st }}$ January 2005 while that in Canada the retained date is the $1^{\text {st }}$ January 2011. However, for these countries, the entities were obliged to collect data according to IFRS since the opening exercise of the last year of implementation of IFRS. In China which has opted for an incomplete convergence, the date of application of the New Chinese accounting standards is the $1^{\text {st }}$ January 2007 with no requirement to collect data according to the new converged accounting standards since the opening exercise of the last year of the implementation. 


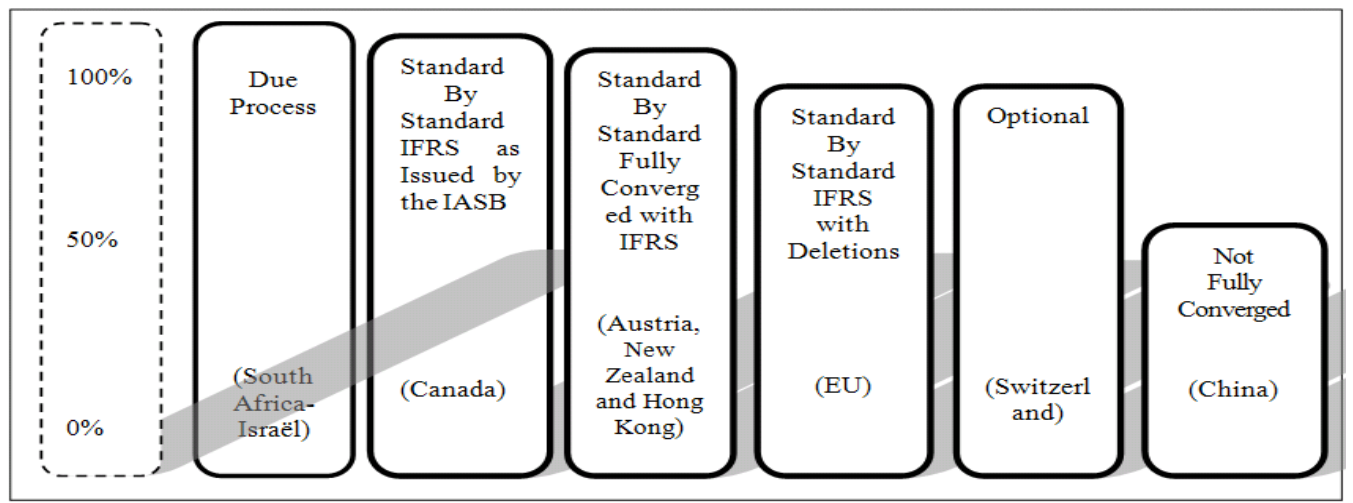

Figure 1. Methods of Implementation of IFRS for listed companies established by Zeef and Nobes

The figure 1 illustrates the classification established by Zeff and Nobes (2010) of methods of implementation of IFRS. It shows the four methods of implementation of IFRS for listed companies: "Due Process", "Standard By Standard” with its 3 sub-methods, "Optional” and the "Not Fully Converged" implementation. It demonstrates the compliance of these methods and sub-methods of implementation with the IFRS issued by the IASB and gives some examples of adopters' countries.

\subsection{The Relevance of accounting information}

The study of the relevance of accounting information for the determination of the continuous informational value (called utility of accounting approach) has retained the attention of several researchers in accounting since the work of Fischer (1911). Generally two approaches were chosen by the researchers for the treatment of this subject: The utilitarian approach and the economic approach.

\subsubsection{The Utilitarian approach of measure of the Value}

The utilitarian approach considers accounting as a principal provider of financial information. This approach has been criticized for its inability to predict the economic and the financial difficulties of firms. Researches that have used this approach can be classified into two categories: Those measuring the results and those searching to aggregate the measure of the financial value.

For the researchers using the results for the determination of the value of the company, these latter consider the accounting profits as a "proxy" of the financial value of the company. The supporters of this approach argue the idea that the accounting profit is the only relevant determinant of the value of a firm. The empirical studies analyzing the relevance of accounting information trough this approach have been significantly influenced by the studies of Fisher (1911), Lindhall (1933) and Hicks (1946). These researches aim to determine the capacity of the accounting information to help the investors to make decisions as specified by Easton et al. (1992). Thus, they have evaluated the informational content of the accounting 
information by the study of the reaction of financial market after the announcement of accounting income. The majority of these empirical studies have adopted the methodologies of "reaction studies" or "event studies".

Other researchers have used the results for the determination of the value of the company. These latter have used another approach called the approach measuring the "true value". This approach is centered on the methodology of "association studies". The object of this methodology highlighted by Beaver and al $(1980,1989)$ and Collins and Kothari (1989) is to reduce the margin of error of models analyzing the relationship between the accounting information and the market value. These studies dissect the value of the company into three components: the "true value" which is the perfect measurement, the "systematic error" that measures the factors that are not identified by the explanatory variables and the "random error" that represent the hazard that distorts the measure of the value.

The second category of researches using the utilitarian approach to measure the global financial value has exploited the complementarity between the various determinants of the value. This approach is called "abnormal profit". Thanks to works of Ohlson (1995) and Feltham and Ohlson (1995) this approach initiated by Preinreich (1938) has been revived. The researches using this approach can be split in two typologies: The first one is called "imperfect measurement approach of the value" and the second one is named "evaluation by the abnormal earnings approach".

The objective of the approach of the imperfect measurement is to remedy to weaknesses of the informational content of accounting earnings in various contexts. It has led the accounting researchers to identify other determinants of accounting value (Dumontier and Raffournier, 2002). In fact, the empirical studies using this approach as highlighted by Walker (1997) reject the idea of measure of the value only by the results and consider the result as a measure among others. Two orientations are identified: The first one is focused on seeking the alternatives determinants of profit and is based on "comparative studies associations". It consists in the comparison of various determinants of the accounting information with the result and the informational content of these determinants with the quality of the representation of the regression. The second orientation considers that the profit is not the only variable to explain the stock market value, but there are other determinants that allow accountants to further clarify the information content of the value.

The approach of evaluation of a firm by the abnormal earnings expresses the value of a company by the amount of capital invested and the future wealth created by the entity. Reflected in accounting terms, the model becomes equal to the sum of the book value of equity and the actualized abnormal earnings. The first work considering this approach is Ohlson (1995) and Feltham and Ohlson (1995). These authors start from a logic based on the distribution of wealth to guide their analysis to the measure of the wealth created by the use of the model of abnormal earnings. Bernard (1995) explains that the evaluation by the abnormal earnings approach is considered as a "mixed" approach because it includes several information from the balance sheet and the income statement. 


\subsubsection{The Economic approach of measure of the Value}

The economic approach of the measure of the value of a firm implies that the accounting information is an economic good that is traded on a market. It supposes therefore an economic rationality. The supply and the demand of information by an economic agent are used to enable a rational choice between several possibilities. In this sense the economic agent will opt for the possibility that maximize its usefulness. At this stage of analysis, the information is fed into decision models. Thus, the information is relevant if its measure of the expected utility is uppermost (Salanie, 1994).

If we transpose the economic logic to accountancy, the supply and the demand of accounting information are dependent on various heterogeneous behaviors of producers and users of accounting information. Walker (1988) considers that the economic approach of measure of the value provides a "scientific" vision of the accounting information because it helps to solve the problems raised mainly by the followers of the positive accounting theory (Jensen 1976, p 11).

In terms of period and purpose, this approach can be divided into three phases: a first phase that has marked the accounting researches of the $70 \mathrm{~s}$ and the $80 \mathrm{~s}$ wishing to establish a theoretical basis of the value. Next, a second phase has begun in the late of the 80s. Its objective is to examine the influence of the alternatives on the choice of policies of evaluation of the company by borrowing the economic concepts of information. A third phase has focused on the study of the asymmetry of the information between managers / investors and investors / investors (Walker 1988).

\subsubsection{Comparison between the approaches and choice of the appropriate model}

The economic approach of measure of the accounting information aims to implement a new accounting research methodology for the evaluation of a company. In the assumption of an efficiency of information and a rationality of economic agents, the economic approach offers a "theoretical basis" model for the measure of the value of a firm. Indeed, this approach wants to remedy to weaknesses of the utilitarian approach. The reflections of Feltham (1968) and Butterworth (1972) on a possible merger between the economic approach of accounting information and the utilitarian approach via the reconciliation between the economic measure and the accounting value of the company has retained the interest of several searchers.

In terms of number and importance of results, the utilitarian approach of measure of the accounting information remains the dominant approach in terms of number and results of research. In comparison with the economic approach, the empirical studies of the utilitarian approach have succeed to explain the information content of the stock prices in a fairly meaningful way. Some models reached a maximum of $90 \%$ as illustrated by the table 1 below. 
Table 1. Results of some important previous studies on the relevance of accounting information

\begin{tabular}{|c|c|c|c|c|c|}
\hline Author & $\begin{array}{l}\text { Study } \\
\text { Period }\end{array}$ & Country & Sample & Results & Model Used \\
\hline Bernard (1995) & $1978-1993$ & United States & $\begin{array}{l}\text { Between } 670 \text { et } 712 \\
\text { Firm/Year. }\end{array}$ & $29 \%<\mathrm{R}^{2}<68 \%$ & $\begin{array}{l}\text { Dividend Discount Model and } \\
\text { Residual Income model }\end{array}$ \\
\hline $\begin{array}{l}\text { Frankel \& Lee } \\
(1996)\end{array}$ & $\begin{array}{l}1987 \\
1994\end{array}$ & 20 Countries & $\begin{array}{l}24909 \\
\text { observations }\end{array}$ & $70 \%<\mathrm{R}^{2}<90 \%$ & Residual Income Model \\
\hline $\begin{array}{l}\text { Gragham \& King } \\
\text { (1998) }\end{array}$ & $\begin{array}{l}1987 \\
1996\end{array}$ & $\begin{array}{l}6 \quad \text { Asiatic } \\
\text { countries }\end{array}$ & 3655 observations & $16 \%<\mathrm{R}^{2}<90 \%$ & Residual Income model \\
\hline $\begin{array}{l}\text { Dechow \& al. } \\
\text { (1999) }\end{array}$ & $\begin{array}{l}1976 \\
1995\end{array}$ & United States & 50133 observations & $8 \%<\mathrm{R}^{2}<40 \%$ & Residual Income model \\
\hline $\begin{array}{l}\text { Abukari \& } \\
\text { McConomy (2000) }\end{array}$ & $\begin{array}{l}1992 \\
1996\end{array}$ & Canada & 2090 observations & $53 \%<\mathrm{R}^{2}<68 \%$ & Dividend discount model \\
\hline $\begin{array}{l}\text { Francis \& al. } \\
(2000)\end{array}$ & $\begin{array}{l}1989 \\
1993\end{array}$ & United States & 2907 observations & $74 \%<\mathrm{R}^{2}<90 \%$ & Residual Income model \\
\hline $\begin{array}{l}\text { Shores \& Bowen } \\
\text { (2002) }\end{array}$ & $\begin{array}{l}1976 \\
1997\end{array}$ & United States & 222 observations & $\begin{array}{l}52 \%<\quad \mathrm{R}^{2} \\
<76 \%\end{array}$ & Economic determinants \\
\hline
\end{tabular}

The Table 1 below provides a synthesis of results founded by some previous researches. It shows the importance in terms of number and results of searches using the utilitarian approach compared to the economic approach.

Based on the results of previous researches mentioned above, our choice in terms of approach is focused on the utilitarian approach.

\section{Hypotheses Development}

Several researches have studied the effects of the adoption of IFRS. An important part of these studies has concerned the countries of the European Union. In terms of results, several of these researches have proved that the adoption of IFRS has a positive impact on the quality of accounting information and that these standards have changed positively the constitution of several accounting and financial indicators that investors use to make decisions. These positive results have differed between the countries.

Taking as base the work of Zeef and Nobes who have proposed a classification of methods of 
implementation of IFRS according to their compliance with the IFRS issued by the IASB. These authors have enunciated that the methods of implementation of IFRS chosen in countries such as South-Africa, Israel, Canada and Australia are compliant, those adopted by the European Union and the Switzerland are possibly compliant and the method chosen in China is Unlikely compliant with the IFRS issued by the IASB. Taking into account several results of previous studies showing the positive effect of the implementation of IFRS on the relevance of accounting information as illustrated by Morais and Curto (2009) who have noted through a sample of companies listed in 14 European countries that the relevance of the value of the financial statements of these countries has increased following their transition to IFRS, Chalmers et al. (2008) have found that the IFRS communicate more additional information for the investors in relation with the goodwill that the Australian standards and have shown (2011) that the benefits have become more relevant following the implementation of IFRS; these results demonstrate that the effect of IFRS on the relevance of accounting information is variable from a country to another; thus, these results leads to the first hypothesis:

H1: The Compliance of methods of implementation of IFRS with the IFRS issued by the IASB chosen influences the relevance of accounting information.

The difference of results illustrated by several studies demonstrate a better relevance of accounting information established in IFRS compared to the local accounting standards of several countries as proved by the study of Auer (1996) which have established that the information in IAS were moderately higher in informational content than the Swiss standards, the work of Bartov, Goldberg and Kim (2005) showing the high significant superiority of IFRS compared to the German local repository, Eccher and Healy (2000) which have founded that the accounting information in IFRS was slightly more relevant than Chinese standards; this prompts the second research hypothesis::

H2: The relevance of accounting information for the countries opting for a compliant method of implementation of IFRS has been more improved than that of countries that have opted for methods which are not compliant.

\section{Methodology}

In the present subsections, we present the data, the model used and explain how we compute our empirical measure of the relevance.

\subsection{Sample Selection and statistics}

The sample that we have chosen consists of companies listed on the stock market of six different countries. Each of these latter has opted for a different method of implementation of IFRS. Thus, the firms in our sample are listed on the main segment of the following markets: Israel, Canada, Hong Kong, France, Switzerland and China.

For the stock market data and the accounting data, they are from the Data base S\&P Capital IQ. The observation period is 13 years from 2000 to 2012.

However, we have initiated a number of adjustments and eliminations in order to ensure 


\section{Macrothink}

Asian Journal of Finance \& Accounting

ISSN 1946-052X

2014, Vol. 6, No. 2

representativeness of the sample and avoid bias that can affect the results of our research. Thus, we have:

- Eliminated companies whose observations are not complete: information on equity, earnings, stock prices and standards adopted;

- Eliminated the extreme observations on equity, earnings, stock market value.

Table 2. Sample of companies selected by country

\begin{tabular}{|c|c|c|c|c|}
\hline \multirow{3}{*}{$\begin{array}{c}\text { Implementation Method / } \\
\text { Sub-Method } \\
\text { Countries } \\
\end{array}$} & \multicolumn{4}{|c|}{ Standard By Standard } \\
\hline & Adoption & $\begin{array}{l}\text { As issued by } \\
\text { the IASB }\end{array}$ & Fully Converged & Used For \\
\hline & Israel & Canada & Hong Kong & \\
\hline Selected Companies & 88 & 399 & 191 & Model 2 \\
\hline Initial observations & 3674 & 16451 & 7842 & \\
\hline Observations Retained & 3432 & 15561 & 7449 & \\
\hline \multirow{4}{*}{ Implementation Method } & Standard By & & & \\
\hline & Standard & & & \\
\hline & As issued by the & Optional & Not Fully & \\
\hline & $\begin{array}{l}\text { IASB but with } \\
\text { deletions }\end{array}$ & & Converged & \\
\hline Countries & United Kingdom & Switzerland & China & \\
\hline Selected Companies & 200 & 53 & 651 & \\
\hline Initial observations & 7954 & 2145 & 21623 & \\
\hline Observations Retained & 7800 & 2067 & 20625 & \\
\hline Total of Selected & & 1582 & & \\
\hline \multicolumn{5}{|l|}{ Companies } \\
\hline Total of Initial & & 59689 & & Model 1 \\
\hline \multicolumn{5}{|l|}{ Observations } \\
\hline Total of Observations & & 56935 & & \\
\hline Retained & & & & \\
\hline
\end{tabular}

Source: The observations are from the database S\&P Capital IQ

The table 3 below provides descriptive statistics of the sample for the variables (Market value at the end of period, Earning per share and Book Value per Share) 
Table 3. Descriptive statistics of the sample by country

\begin{tabular}{|c|c|c|c|c|c|c|c|c|c|c|c|c|c|c|c|c|}
\hline \multirow{2}{*}{ Countries } & \multicolumn{2}{|c|}{ N. Firms } & \multicolumn{2}{|c|}{ Average } & \multicolumn{2}{|c|}{$\begin{array}{c}\text { St. } \\
\text { Deviation }\end{array}$} & \multicolumn{2}{|c|}{ Q1 } & \multicolumn{2}{|c|}{ Q2 } & \multicolumn{2}{|c|}{ Q3 } & \multicolumn{2}{|c|}{ Min. } & \multicolumn{2}{|c|}{ Max. } \\
\hline & Bef & Aft & Bef & Aft & Bef & Aft & Bef & Aft & Bef & Aft & Bef & Aft & Bef & Aft & Bef & Aft \\
\hline Israel & & & & & & & & & & & & & & & & \\
\hline $\mathbf{P}$ & 88 & 88 & 7.2 & 8.1 & 2,12 & 2.35 & 0.9 & 1.10 & 2.4 & 2.1 & 6.1 & 5.6 & 0.01 & 0.06 & 1348 & 1847 \\
\hline EPS & 88 & 88 & 0.8 & 2.7 & 3,12 & 3.23 & 0.2 & .3 & 3.1 & 2.8 & 4.3 & 4.9 & 0.03 & 0.08 & 547 & 614 \\
\hline BVS & 88 & 88 & 6.8 & 8.5 & 3,43 & 3.12 & 0 & 0,1 & 4.1 & 3.8 & 6.8 & 6.4 & 0.04 & 0.02 & 6513 & 7784 \\
\hline Canada & & & & & & & & & & & & & & & & \\
\hline $\mathbf{P}$ & 399 & 399 & 9,8 & 11 & 4,2 & 3.23 & 0.5 & 0.50 & 5.2 & 4.2 & 5.2 & 9.3 & 0.06 & 0.04 & 5479 & 4384 \\
\hline EPS & 399 & 399 & 0.7 & 1.1 & 3.1 & 3.13 & 0.9 & .9 & 1.6 & 1.9 & 6.9 & 7.6 & 0.09 & 0.06 & 1032 & 1971 \\
\hline BVS & 399 & 399 & 4.1 & 7.3 & 2,4 & 2.3 & 0.0 & 0.0 & 3.6 & 3.7 & 3.8 & 4.1 & 0.08 & 0.01 & 8451 & 7541 \\
\hline Hong Kong & & & & & & & & & & & & & & & & \\
\hline $\mathbf{P}$ & 191 & 191 & 24 & 29 & 2,12 & 2,12 & 1.5 & 1.7 & 2.9 & 3.2 & 3.7 & 3.2 & 0.07 & 0.06 & 8746 & 8674 \\
\hline EPS & 191 & 191 & 0.5 & 4.1 & 1.1 & 1.1 & 0.0 & 0.1 & 3.7 & 4.9 & 4.6 & 4.9 & 0.06 & 0.03 & 1245 & 1351 \\
\hline BVS & 191 & 191 & 16 & 21 & 2.2 & 2.2 & 1.7 & 1.4 & 4.5 & 4.1. & 7.2 & 8.7 & 0.02 & 0.01 & 9784 & 9478 \\
\hline U.K. & & & & & & & & & & & & & & & & \\
\hline $\mathbf{P}$ & 200 & 200 & 40 & 47 & 1.2 & 1.2 & 0.3 & 0.21 & 3.3 & 2.1 & 6.3 & 5.1 & 0.02 & 0.01 & 9745 & 9614 \\
\hline EPS & 200 & 200 & 0.3 & 0.2 & 2.1 & 2.1 & 1 & .4 & 1.8 & 1.6 & 6.2 & 6.6 & 0.01 & 0.04 & 546 & 614 \\
\hline BVS & 200 & 200 & 2 & 2.1 & 1.4 & 1.4 & 0.2 & 0.1 & 2.0 & 2.3 & 5.9 & 7.5 & 0.01 & 0.02 & 7548 & 7798 \\
\hline Switzerland & & & & & & & & & & & & & & & & \\
\hline $\mathbf{P}$ & 53 & 53 & 15 & 12 & 2.12 & 2.12 & 0.11 & 0.1 & 3.1 & 4.11 & 5.2 & 5.7 & 0.05 & 0.03 & 8451 & 9475 \\
\hline EPS & 53 & 53 & 0.7 & 0.6 & 4.12 & 4.12 & 0.1 & 0.0 & 4.4 & 5.1 & 9.4 & 8.4 & 0.01 & 0.01 & 951 & 784 \\
\hline BVS & 53 & 53 & 11 & 10 & 3.12 & 3.12 & 1 & 1,4 & 4.6 & 3.1 & 7.6 & 6.7 & 0.04 & 0.02 & 8457 & 7845 \\
\hline China & & & & & & & & & & & & & & & & \\
\hline $\mathbf{P}$ & 651 & 651 & 1.2 & 1.5 & 2.4 & 2.4 & 0.2 & 0.1 & 3.4 & 3.7 & 6.5 & 5.8 & 0.01 & 0.01 & 7458 & 9645 \\
\hline EPS & 651 & 651 & 0.1 & 0.2 & 0.1 & 0.1 & 0.4 & 0.5 & 4.8 & 5.9 & 7.8 & 7.4 & 0.08 & 0.04 & 647 & 754 \\
\hline BVS & 651 & 651 & 0.4 & 3.1 & 0.8 & 0.8 & 0.1 & 0.0 & 6.1 & 6.4 & 6.8 & 6.9 & 0.04 & 0.01 & 8472 & 9457 \\
\hline
\end{tabular}

Source: The observations are from the database S\&P Capital IQ

\subsection{Empirical Model}

The basic model that we use to measure the relevance of accounting information is the result of work of Ohlson (1995) and Feltham and Ohlson (1995). This model represents a current of 
research of the evaluation of the value of a firm. Using a conventional approach of evaluation, it establishes a link between the financial statements and the market value. The approach of Feltham-Ohlson using accounting information for the financial evaluation simplifies the perception of this link: from the accounting data we pass directly to the value of market without the detour through the forecast dividends. This model has increased the productivity and has simplified the theoretical approach of evaluation of a firm.

This model highlights the importance of the accounting information that has been overlooked or undervalued by the financials for a long time. The Ohlson model represents the price at the end of the period via the earnings per share and the equity per share:

Model (1):

$$
\mathrm{P}_{\mathrm{it}}=\mathrm{B}_{0}+\mathrm{B}_{1} \mathrm{EPS}_{\mathrm{it}}+\mathrm{B}_{2} \mathrm{BVS}_{\mathrm{it}}+\mathrm{B}_{3} \text { Compliance }_{\mathrm{t}}+\mathrm{e}_{\mathrm{it}}
$$

Model (2):

$$
\mathrm{P}_{\mathrm{it}}=\mathrm{B}_{0}+\mathrm{B}_{1} \mathrm{EPS}_{\mathrm{it}}+\mathrm{B}_{2} \mathrm{BVS}_{\mathrm{it}}+\mathrm{e}_{\mathrm{it}}
$$

With:

$\mathrm{P}_{\text {it }}$

: $\quad$ The Stock Market Value of the firm i at the end of year t (31/12/t);

$\mathrm{EPS}_{\text {it }}$

: The Ratio of earnings per share of firm i in year $t$;

$\mathrm{BVS}_{\text {it }}$

: The Ratio of equity per share related to firm $\mathrm{i}$ in year $\mathrm{t}$;

Compliance $_{\mathrm{t}}$ : A dichotomous variable witch takes the value 0 in the case of no compliant of the Method of implementation chosen by the country to IFRS issued by the IASB and the Value 1 otherwise;

\section{$\mathrm{e}_{\mathrm{it}} \quad$ : Other informational pertinence of firm $\mathrm{i}$ in year $\mathrm{t}$}

Thus, we use the Model 1 for the study of the effect of the compliance of the method of implementation of IFRS on the relevance of accounting information. The Model 2 is used for the comparison of the relevance between the countries adopting different methods of implementation of IFRS.

\section{Results}

To study the relevance of accounting information we have used the coefficient of determination R2. This coefficient shows the percentage of values explained by the proposed model. We have obtained the following results presented by Model.

5.1. A significant effect of the compliance of the method of implementation of IFRS on the relevance

The objective of the model 1 is to see if the compliance of the method of implementation chosen by a country influences the relevance of the accounting information. The analysis period is three years. The choice of this period is limited by the date of implementation of IFRS in Canada, the only one country having chosen the method of implementation called "IFRS as Issued by the IASB". Indeed, since 2011, the application of IFRS is mandatory for listed companies of Canada with an obligation to prepare the accounting information in IFRS for the previous year. 


\section{Macrothink}

The results founded for the model 1 are quite significant with a coefficient of determination between 73\% and 78\% and a F. test between 602 and 624 for the years 2010, 2011 and 2012. These results reflect the good capacity of the model to explain the value of the stock market by accounting variables EPS and BVS and the dummy variable compliance.

In terms of variables, the results demonstrate that the three variables EPS, BVS and Compliance are significant at a level of 1\% for the three years studied for the model1: 2010, 2011 and 2012. Thus, the compliance of the method chosen by a country with the IFRS issued by the IASB influences the relevance of accounting information. Also, the analysis of coefficient $B 3$ of the variable compliance shows that the relationship of this variable with the dependent variable is positive.

In terms of relevance of accounting information of all the countries of the sample having implemented the IFRS, the analysis of the coefficient of determination shows that the accounting information established in IFRS is relevant for the ensemble of the countries and explains the stock market value of listed companies.

Table 4. Results of Model 1

\begin{tabular}{|c|c|c|c|c|}
\hline \multicolumn{5}{|c|}{$\mathrm{M}(1): \mathrm{P}_{\mathrm{it}}=\mathrm{B}_{0}+\mathrm{B}_{1} \mathrm{EPS}_{\mathrm{it}}+\mathrm{B}_{2} \mathrm{BVS}_{\mathrm{it}}+\mathrm{B}_{3}$ Compliance $_{\mathrm{t}}+\mathrm{e}_{\mathrm{it}}$} \\
\hline & & 2010 & 2011 & 2012 \\
\hline \multirow[t]{3}{*}{ Constant } & $\mathrm{B}_{0}$ & $-15,1450$ & $-78,1140$ & $-64,0090$ \\
\hline & $\mathrm{t}$ & $-2,5040$ & $-3,9123$ & $-3,8240$ \\
\hline & Sign. & 0,0140 & 0,0000 & 0,0000 \\
\hline \multirow[t]{3}{*}{ EPS } & $\mathrm{B}_{1}$ & 0,6340 & 0,4240 & 0,3140 \\
\hline & $\mathrm{t}$ & 7,4510 & 11,5350 & 6,5470 \\
\hline & Sign. & 0,0000 & 0,0000 & 0,0000 \\
\hline \multirow[t]{3}{*}{ BVS } & $\mathrm{B}_{2}$ & 0,7470 & 0,5450 & 0,6540 \\
\hline & $\mathrm{t}$ & 35,9670 & 34,0100 & 38,2740 \\
\hline & Sign. & 0,0000 & 0,0000 & 0,0000 \\
\hline \multirow[t]{3}{*}{ Compliance } & $\mathrm{B}_{3}$ & 1,4870 & 2,0990 & 1,5780 \\
\hline & $\mathrm{t}$ & 4,6480 & 4,4570 & 4,9780 \\
\hline & Sign. & 0,0000 & 0,0000 & 0,0000 \\
\hline $\mathrm{R} 2$ & & 0,7841 & 0,7490 & 0,7304 \\
\hline $\mathrm{F}$ & & 624,12 & 602,14 & 621,94 \\
\hline Durbin Watson & & 1,41200 & 1,6412 & 1,7170 \\
\hline
\end{tabular}

\subsection{Different degrees of improvement of the relevance following the Implementation of IFRS}

The analysis of results of the regression of model 2 shows that the degree of variation following the transition to IFRS differs from a country to another. In fact, this variation is positive and very important for the countries as the United Kingdom that has opted for the method of implementation "IFRS with deletion", Hong Kong adopting a "Full convergence" method and Israel implementing the IFRS by the "Due Process method".

Thus, in Israel, Honk Kong, United Kingdom and Switzerland, the examination of results 


\section{Macrothink}

Asian Journal of Finance \& Accounting

ISSN 1946-052X 2014, Vol. 6, No. 2

shows that for the years following the transition to IFRS, the R2 was high which demonstrates a very good performance. This performance has been maintained at a high level after the application of IFRS with a coefficient R2 between $49 \%$ and $91 \%$. In comparison between the period before and after the implementation of IFRS, the results demonstrate that the implementation of IFRS has improved the relevance of accounting information In Israel, Honk Kong, United Kingdom and Switzerland. In Canada, the results demonstrate that the relevance of accounting information has been maintained following the implementation of IFRS. In china which has adopted a "not fully converged method" for the implementation of IFRS, the results demonstrate a decrease in relevance following the transition to IFRS.

Table 5. Comparison of the evolution of R2 of Model 2 by country

\begin{tabular}{|c|c|c|c|c|c|c|c|c|c|c|c|c|c|c|}
\hline Country & Method & 2000 & 2001 & 2002 & 2003 & 2004 & 2005 & 2006 & 2007 & 2008 & 2009 & 2010 & 2011 & 2012 \\
\hline Israel & D.P. & $48 \% *$ & $39 \% *$ & $34 \% *$ & $41 \% *$ & $39 \% *$ & $41 \% *$ & $36 \% *$ & $84 \% *$ & $69 \% *$ & $74 \% *$ & $67 \% *$ & $89 \% *$ & $86 \% *$ \\
\hline Canada & I.I. & $39 \% *$ & $23 \% *$ & $56 \% *$ & $37 \% *$ & $25 \% *$ & $60 \% *$ & $44 \% *$ & $85 \% *$ & $96 \% *$ & $95 \% *$ & $89 \% *$ & $80 \% *$ & $84 \% *$ \\
\hline Hong Kong & F.C. & $0,2 \%$ & $0,1 \%$ & $3 \%$ & $1 \%$ & $4 \%$ & $1 \%$ & $3 \%$ & $9 \%$ & $83 \% *$ & $73 \% *$ & $78 \% *$ & $49 \% *$ & $58 \% *$ \\
\hline United Kingdom & I.D. & $0,2 \%$ & $0,8 \%$ & $0,3 \%$ & $0,4 \%$ & $1,7 \%$ & $92 \% *$ & $94 \% *$ & $91 \% *$ & $92 \% *$ & $63 \% *$ & $84 \% *$ & $72 \% *$ & $70 \% *$ \\
\hline Switzerland & O.A. & $46 \% *$ & $41 \% *$ & $57 \% *$ & $43 \% *$ & $49 \% *$ & $34 \% *$ & $46 \% *$ & $37 \% *$ & $91 \% *$ & $85 \% *$ & $80 \% *$ & $75 \% *$ & $77 \% *$ \\
\hline China & N.C. & $88 \% *$ & $96 \% *$ & $98 \% *$ & $95 \% *$ & $96 \% *$ & $94 \% *$ & $88 \% *$ & $53 \% *$ & $91 \% *$ & $83 \% *$ & $82 \% *$ & $73 \% *$ & $76 \% *$ \\
\hline
\end{tabular}

D.P.: Due Process;

I.I.: As Issued By the IASB;

F.C.: Fully Converged;

* Sig. $1 \%$

I.D.: IFRS with Deletions; O.A.: Optional adoption;

I.C.: Not Fully Converged;

After IFRS

The table 5 above illustrates the variation of coefficient of determination R2 for the two periods before and after the transition to IFRS. It indicates an improvement of R2 following the transition to IFRS in Israel, Hong Kong, United Kingdom and Switzerland. A contrary result is observed in china. In Canada, the relevance of accounting information for the period after the implementation of IFRS has been maintained in a high level. 
Macrothink $\Delta$ Institute ${ }^{\text {tI }}$
Asian Journal of Finance \& Accounting

ISS 1946-052X

2014, Vol. 6, No. 2
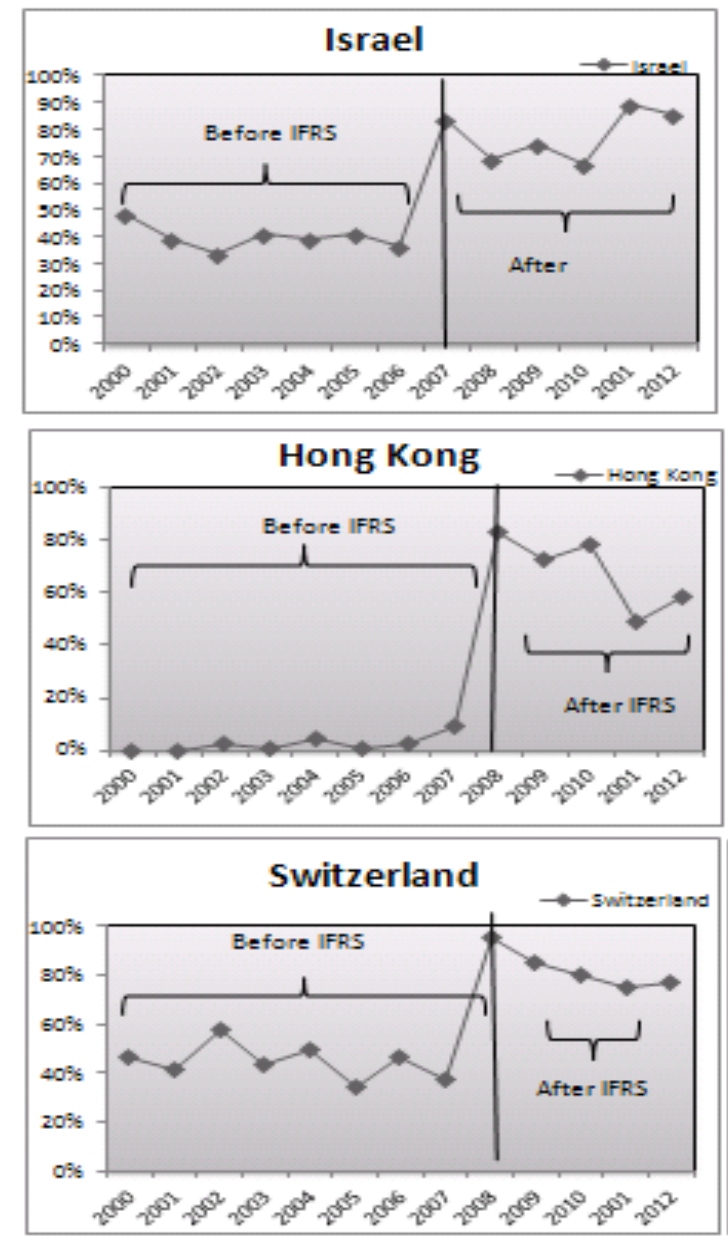
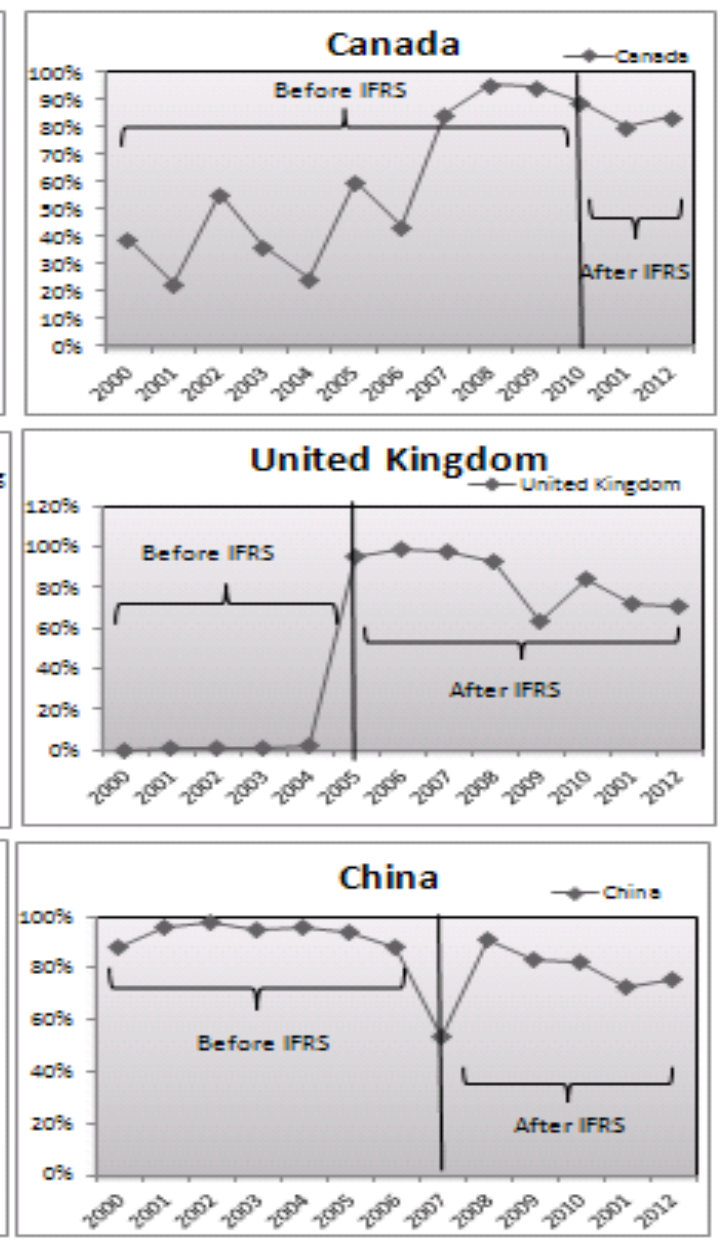

Figure 2. Evolution of R2 for the period before and after the implementation of IFRS

231

www.macrothink.org/ajfa 
Table 6. Model results In Israel (Due process method- Compliant)

\begin{tabular}{|c|c|c|c|c|c|c|c|c|c|c|c|c|c|c|}
\hline \multirow{2}{*}{ ن } & \multirow[b]{2}{*}{ Year } & \multicolumn{3}{|c|}{ Constant } & \multicolumn{3}{|c|}{ EPS } & \multicolumn{3}{|c|}{ BVS } & \multirow{2}{*}{$\mathbf{F}$} & \multirow{2}{*}{ Sig. F } & \multirow{2}{*}{$\mathbf{R} 2$} & \multirow{2}{*}{ D. W. } \\
\hline & & B0 & $\mathbf{t}$ & Sig. & B1 & $\mathbf{t}$ & Sig. & B2 & $\mathbf{t}$ & Sig. & & & & \\
\hline \multirow{15}{*}{ 莺 } & 2000 & $-0,07$ & $-0,03$ & 0,9660 & 7,24 & 10,12 & 0,0000 & 1,47 & 1,32 & 0,1960 & 194,21 & 0,0000 & $48 \%$ & 1,24 \\
\hline & 2001 & $-0,51$ & $-0,64$ & 0,3260 & 14,13 & 14,15 & 0,0000 & 1,27 & 3,21 & 0,0020 & 145,24 & 0,0000 & $39 \%$ & 1,83 \\
\hline & 2002 & $-0,23$ & $-0,84$ & 0,2720 & 5,31 & 5,45 & 0,0000 & 1,84 & 3,97 & 0,0010 & 138,30 & 0,0000 & $34 \%$ & 1,74 \\
\hline & 2003 & $-2,56$ & $-2,53$ & 0,0630 & 14,22 & 6,08 & 0,0000 & 1,27 & 3,14 & 0,0050 & 148,27 & 0,0000 & $41 \%$ & 1,84 \\
\hline & 2004 & $-0,09$ & $-0,05$ & 0,9400 & $-2,01$ & $-3,54$ & 0,0029 & 2,05 & 4,84 & 0,0000 & 145,87 & 0,0000 & $39 \%$ & 1,86 \\
\hline & 2005 & $-1,34$ & $-0,61$ & 0,3830 & $-2,77$ & $-1,10$ & 0,1612 & 3,21 & 4,77 & 0,0000 & 38,36 & 0,0000 & $41 \%$ & 1,24 \\
\hline & 2006 & $-2,13$ & $-2,56$ & 0,0320 & 4,42 & 2,00 & 0,0009 & 1,47 & 3,95 & 0,0010 & 140,12 & 0,0000 & $36 \%$ & 1,43 \\
\hline & 2007 & 6,74 & 2,23 & 0,0290 & 6,06 & 2,86 & 0,0000 & 2,09 & 4,84 & 0,0000 & 1324,9 & 0,0000 & $84 \%$ & 2,47 \\
\hline & 2008 & 0,52 & 1,41 & 0,1940 & 2,25 & 2,83 & 0,0056 & 1,74 & 5,36 & 0,0000 & 412,42 & 0,0000 & $69 \%$ & 2,31 \\
\hline & 2009 & 3,14 & 1,12 & 0,0620 & 7,41 & 1,24 & 0,2789 & 3,88 & 7,98 & 0,0000 & 854,12 & 0,0000 & $74 \%$ & 1,97 \\
\hline & 2010 & 3,74 & 2,41 & 0,0950 & 1,64 & 0,54 & 0,5421 & 2,14 & 6,45 & 0,0000 & 309,08 & 0,0000 & $67 \%$ & 1,64 \\
\hline & 2011 & 2,41 & 1,12 & 0,0410 & 1,54 & 1,21 & 0,1347 & 1,24 & 6,48 & 0,0000 & 1621,9 & 0,0000 & $89 \%$ & 2,07 \\
\hline & 2012 & 0,27 & 0,21 & 0,3410 & 1,23 & 0,59 & 0,5140 & 2,24 & 10,43 & 0,0000 & 1420,0 & 0,0000 & $86 \%$ & 2,01 \\
\hline & $\mu$ Before & & & & & & & & & & & & $39,71 \%$ & \\
\hline & $\boldsymbol{\mu}$ After & & & & & & & & & & & & $78,16 \%$ & \\
\hline
\end{tabular}

Table 7. Model results In Canada (As issued by the IASB method- Compliant)

\begin{tabular}{|c|c|c|c|c|c|c|c|c|c|c|c|c|c|c|}
\hline \multirow{2}{*}{ ن } & \multirow[b]{2}{*}{ Year } & \multicolumn{3}{|c|}{ Constant } & \multicolumn{3}{|c|}{ EPS } & \multicolumn{3}{|c|}{ BVS } & \multirow{2}{*}{$\mathbf{F}$} & \multirow{2}{*}{ Sig. F } & \multirow{2}{*}{ R2 } & \multirow{2}{*}{ D. W. } \\
\hline & & B0 & t & Sig. & B1 & t & Sig. & B2 & $\mathrm{t}$ & Sig. & & & & \\
\hline \multirow{15}{*}{ 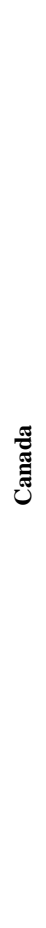 } & 2000 & 3,68 & 3,47 & 0,0001 & $-8,24$ & $-5,78$ & 0,0000 & 1,34 & 17,24 & 0,0000 & 145,21 & 0,0000 & $39 \%$ & 2,00 \\
\hline & 2001 & 4,51 & 5,21 & 0,0000 & 1,04 & 0,94 & 0,2450 & 0,34 & 4,89 & 0,0000 & 74,21 & 0,0000 & $23 \%$ & 2,01 \\
\hline & 2002 & 2,50 & 6,04 & 0,0000 & $-2,96$ & $-4,44$ & 0,0000 & 0,97 & 18,79 & 0,0000 & 303,72 & 0,0000 & $56 \%$ & 1,98 \\
\hline & 2003 & 3,95 & 3,43 & 0,0001 & $-7,96$ & $-5,01$ & 0,0000 & 1,78 & 14,18 & 0,0000 & 136,37 & 0,0000 & $37 \%$ & 2,00 \\
\hline & 2004 & 6,05 & 6,28 & 0,0000 & 1,01 & 0,95 & 0,3410 & 0,27 & 4,57 & 0,0000 & 76,80 & 0,0000 & $25 \%$ & 2,02 \\
\hline & 2005 & 4,80 & 5,89 & 0,0000 & $-1,77$ & $-2,77$ & 0,0060 & 1,30 & 13,07 & 0,0000 & 347,82 & 0,0000 & $60 \%$ & 2,02 \\
\hline & 2006 & 5,23 & 4,64 & 0,0000 & $-1,95$ & $-1,39$ & 0,1640 & 1,30 & 5,73 & 0,0000 & 184,63 & 0,0000 & $44 \%$ & 2,01 \\
\hline & 2007 & 4,90 & 11,76 & 0,0000 & 2,50 & 9,22 & 0,0000 & 0,57 & 18,94 & 0,0000 & 1326,80 & 0,0000 & $85 \%$ & 1,87 \\
\hline & 2008 & 0,97 & 6,02 & 0,0000 & 1,46 & 21,96 & 0,0000 & 0,74 & 77,48 & 0,0000 & 5399,75 & 0,0000 & $96 \%$ & 2,11 \\
\hline & 2009 & 2,29 & 10,50 & 0,0000 & 3,40 & 21,48 & 0,0000 & 0,68 & 67,83 & 0,0000 & 4275,89 & 0,0000 & $95 \%$ & 1,67 \\
\hline & 2010 & 4,12 & 10,42 & 0,0000 & 0,51 & 1,30 & 0,0910 & 0,80 & 28,58 & 0,0000 & 1828,41 & 0,0000 & $89 \%$ & 1,64 \\
\hline & 2011 & 3,15 & 6,66 & 0,0000 & 1,60 & 5,57 & 0,0000 & 0,69 & 41,01 & 0,0000 & 936,97 & 0,0000 & $80 \%$ & 1,74 \\
\hline & 2012 & 5,12 & 12,51 & 0,0000 & 0,64 & 1,41 & 0,2145 & 0,97 & 30,54 & 0,0000 & 1478,21 & 0,0000 & $84 \%$ & 1,75 \\
\hline & $\mu$ Before & & & & & & & & & & & & $80,25 \% *$ & \\
\hline & $\boldsymbol{\mu}$ After & & & & & & & & & & & & $84,33 \%$ & \\
\hline
\end{tabular}

* The average before the IFRS implementation is based on the R2 of years 2006, 2007, 2008 and 2009 since the information available for the country in IFRS relates 3 years. 
Table 8. Model results In Hong Kong (Full convergence method- Compliant)

\begin{tabular}{|c|c|c|c|c|c|c|c|c|c|c|c|c|c|c|}
\hline \multirow{2}{*}{ U⿺ } & \multirow[b]{2}{*}{ Year } & \multicolumn{3}{|c|}{ Constant } & \multicolumn{3}{|c|}{ EPS } & \multicolumn{3}{|c|}{ BVS } & \multirow{2}{*}{$\mathbf{F}$} & \multirow{2}{*}{ Sig. F } & \multirow{2}{*}{$\mathbf{R} 2$} & \multirow{2}{*}{ D. W. } \\
\hline & & B0 & $\mathbf{t}$ & Sig. & B1 & $\mathbf{t}$ & Sig. & B2 & $\mathbf{t}$ & Sig. & & & & \\
\hline \multirow{15}{*}{ 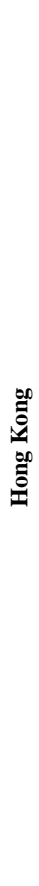 } & 2000 & $-1,21$ & $-0,04$ & 0,9660 & 6,12 & 0,94 & 0,9560 & 1,64 & 3,45 & 0,0000 & 0,37 & 0,9620 & $0,20 \%$ & 2,12 \\
\hline & 2001 & $-1,32$ & $-0,94$ & 0,3560 & 12,21 & 0,84 & 0,9700 & 2,45 & 2,94 & 0,0000 & 0,44 & 0,9951 & $0,10 \%$ & 1,97 \\
\hline & 2002 & $-1,21$ & $-0,73$ & 0,4720 & 5,65 & 0,97 & 0,9701 & 2,89 & 1,95 & 0,000 & 9,41 & 0,3520 & $3 \%$ & 1,84 \\
\hline & 2003 & $-1,64$ & $-2,04$ & 0,0530 & 31,12 & 0,87 & 0,9641 & 2,46 & 3,12 & 0,0050 & 2,06 & 0,0645 & $1 \%$ & 1,34 \\
\hline & 2004 & $-1,24$ & $-0,06$ & 0,9500 & $-5,12$ & 0,06 & 0,9993 & 2,31 & 15,88 & 0,0000 & 12,87 & 0,9412 & $4 \%$ & 1,86 \\
\hline & 2005 & $-1,32$ & $-0,71$ & 0,4830 & $-3,12$ & $-1,38$ & 0,1945 & 3,18 & 7,77 & 0,0000 & 2,36 & 0,0631 & $1 \%$ & 1,54 \\
\hline & 2006 & $-4,24$ & $-2,24$ & 0,0350 & 4,12 & $-2,27$ & 0,0341 & 1,79 & 3,95 & 0,0010 & 9,12 & 0,3412 & $3 \%$ & 1,63 \\
\hline & 2007 & $-4,12$ & $-2,28$ & 0,0310 & 4,12 & $-2,28$ & 0,0340 & 4,12 & 4,33 & 0,0000 & 24,90 & 0,1214 & $9 \%$ & 1,48 \\
\hline & 2008 & 1,65 & 1,36 & 0,1930 & 6,51 & 2,87 & 0,0090 & 2,74 & 3,41 & 0,0000 & 548,01 & 0,0000 & $83 \%$ & 2,21 \\
\hline & 2009 & 3,23 & 1,84 & 0,0780 & 3,21 & 2,76 & 0,0060 & 1,56 & 6,97 & 0,0000 & 406,12 & 0,0000 & $73 \%$ & 2,01 \\
\hline & 2010 & $-2,52$ & 1,64 & 0,1160 & 2,31 & 2,93 & 0,0009 & 1,75 & 5,15 & 0,0000 & 468,10 & 0,0000 & $78 \%$ & 2,07 \\
\hline & 2011 & 3,24 & 2,12 & 0,0460 & 1,45 & 3,64 & 0,0000 & 2,13 & 10,27 & 0,0000 & 142,12 & 0,0000 & $49 \%$ & 2,04 \\
\hline & 2012 & 3,45 & 0,88 & 0,3860 & 2,24 & 4,57 & 0,0000 & 1,41 & 10,39 & 0,0000 & 208,45 & 0,0000 & $58 \%$ & 2,34 \\
\hline & $\mu$ Before & & & & & & & & & & & & $2,66 \%$ & \\
\hline & $\boldsymbol{\mu}$ After & & & & & & & & & & & & $68,2 \%$ & \\
\hline
\end{tabular}

Table 9. Model results In United Kingdom (IFRS with deletions method - Compliant)

\begin{tabular}{|c|c|c|c|c|c|c|c|c|c|c|c|c|c|c|}
\hline \multirow{2}{*}{ 晜 } & \multirow[b]{2}{*}{ Year } & \multicolumn{3}{|c|}{ Constant } & \multicolumn{3}{|c|}{ EPS } & \multicolumn{3}{|c|}{ BVS } & \multirow{2}{*}{$\mathbf{F}$} & \multirow{2}{*}{ Sig. $\mathbf{F}$} & \multirow{2}{*}{$\mathbf{R} 2$} & \multirow{2}{*}{ D. W. } \\
\hline & & B0 & t & Sig. & B1 & $\mathbf{t}$ & Sig. & B2 & t & Sig. & & & & \\
\hline \multirow{15}{*}{ 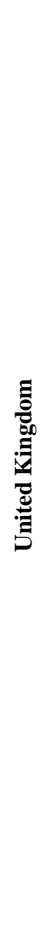 } & 2000 & 3,68 & 0,47 & 0,9751 & $-8,24$ & $-0,24$ & 0,9541 & 1,34 & 0,24 & 0,9541 & 0,94 & 0,9610 & $0,20 \%$ & 2,24 \\
\hline & 2001 & 4,51 & 0,21 & 0,9845 & 1,04 & 0,65 & 0,9314 & 0,34 & 0,89 & 0,9314 & 1,21 & 0,9101 & $0,80 \%$ & 2,13 \\
\hline & 2002 & 2,50 & 1,04 & 0,9101 & $-2,96$ & $-0,87$ & 0,0000 & 0,97 & 0,79 & 0,9145 & 0,98 & 0,9420 & $0,30 \%$ & 1,94 \\
\hline & 2003 & 3,95 & 0,43 & 0,9845 & $-7,96$ & $-0,78$ & 0,0000 & 1,78 & 0,18 & 0,9984 & 1,37 & 0,9254 & $0,40 \%$ & 2,02 \\
\hline & 2004 & 6,05 & 0,28 & 0,9812 & 1,01 & 0,54 & 0,0000 & 0,27 & 0,57 & 0,9465 & 1,14 & 0,8650 & $1,70 \%$ & 2,21 \\
\hline & 2005 & 4,21 & 5,84 & 0,0000 & $-1,77$ & $-2,77$ & 0,0060 & 1,30 & 56,07 & 0,0000 & 5447,82 & 0,0000 & $92 \%$ & 2,11 \\
\hline & 2006 & 5,12 & 4,64 & 0,0000 & $-1,95$ & $-1,39$ & 0,1640 & 1,30 & 58,73 & 0,0000 & 5674,63 & 0,0000 & $94 \%$ & 2,04 \\
\hline & 2007 & 4,12 & 11,76 & 0,0000 & 2,50 & 9,22 & 0,0000 & 0,57 & 64,94 & 0,0000 & 5126,80 & 0,0000 & $91 \%$ & 1,94 \\
\hline & 2008 & 3,32 & 6,02 & 0,0000 & 1,46 & 21,96 & 0,0000 & 0,74 & 77,48 & 0,0000 & 5421,75 & 0,0000 & $92 \%$ & 2,10 \\
\hline & 2009 & 2,65 & 10,50 & 0,0000 & 3,40 & 24,48 & 0,0000 & 0,68 & 24,83 & 0,0000 & 517,89 & 0,0000 & $63 \%$ & 1,97 \\
\hline & 2010 & 4,87 & 10,42 & 0,0000 & 0,51 & 4,30 & 0,0000 & 0,80 & 46,58 & 0,0000 & 867,41 & 0,0000 & $84 \%$ & 1,91 \\
\hline & 2011 & 3,42 & 6,66 & 0,0000 & 1,60 & 5,57 & 0,0000 & 0,69 & 32,01 & 0,0000 & 496,97 & 0,0000 & $72 \%$ & 1,92 \\
\hline & 2012 & 5,35 & 12,51 & 0,0000 & 0,64 & 6,46 & 0,0000 & 0,97 & 29,54 & 0,0000 & 464,21 & 0,0000 & $70 \%$ & 1,97 \\
\hline & $\mu$ Before & & & & & & & & & & & & $0,68 \%$ & \\
\hline & p After & & & & & & & & & & & & $82,25 \%$ & \\
\hline
\end{tabular}


Table 10. Model results In Switzerland (optional method - Compliant))

\begin{tabular}{|c|c|c|c|c|c|c|c|c|c|c|c|c|c|c|}
\hline \multirow{2}{*}{$\begin{array}{l}\stackrel{D}{E} \\
\text { 己े }\end{array}$} & \multirow[b]{2}{*}{ Year } & \multicolumn{3}{|c|}{ Constant } & \multicolumn{3}{|c|}{ EPS } & \multicolumn{3}{|c|}{ BVS } & \multirow{2}{*}{$\mathbf{F}$} & \multirow{2}{*}{ Sig. F } & \multirow{2}{*}{$\mathbf{R} 2$} & \multirow{2}{*}{ D. W. } \\
\hline & & B0 & $\mathbf{t}$ & Sig. & B1 & $\mathbf{t}$ & Sig. & B2 & $\mathbf{t}$ & Sig. & & & & \\
\hline \multirow{15}{*}{ 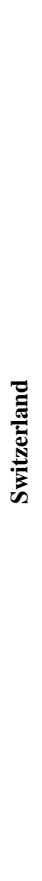 } & 2000 & $-1,78$ & $-0,64$ & 0,4124 & 8,17 & 9,19 & 0,0000 & 0,43 & 1,32 & 0,1960 & 282,01 & 0,0000 & $46 \%$ & 2,85 \\
\hline & 2001 & $-1,32$ & $-0,41$ & 0,5560 & 10,16 & 11,04 & 0,0000 & 1,05 & 3,42 & 0,0020 & 235,12 & 0,0000 & $41 \%$ & 1,82 \\
\hline & 2002 & $-1,12$ & $-0,75$ & 0,3640 & 8,39 & 4,39 & 0,0000 & 1,09 & 1,95 & 0,0630 & 458,40 & 0,0000 & $57 \%$ & 1,63 \\
\hline & 2003 & $-1,65$ & 2,35 & 0,0354 & 16,38 & 5,00 & 0,0000 & 1,54 & 3,12 & 0,0050 & 246,86 & 0,0000 & $43 \%$ & 1,30 \\
\hline & 2004 & $-1,13$ & $-0,71$ & 0,3464 & $-3,07$ & $-3,36$ & 0,0030 & 2,75 & 15,88 & 0,0000 & 295,87 & 0,0000 & $49 \%$ & 1,86 \\
\hline & 2005 & $-3,21$ & $-0,44$ & 0,5230 & $-2,77$ & $-1,40$ & 0,1600 & 4,12 & 7,77 & 0,0000 & 175,36 & 0,0000 & $34 \%$ & 1,03 \\
\hline & 2006 & $-2,22$ & $-2,98$ & 0,0210 & 7,92 & 4,00 & 0,0010 & 2,82 & 3,95 & 0,0010 & 284,12 & 0,0000 & $46 \%$ & 1,44 \\
\hline & 2007 & $-2,12$ & $-2,78$ & 0,0950 & 6,06 & 2,84 & 0,0090 & 4,03 & 4,33 & 0,0000 & 183,90 & 0,0000 & $37 \%$ & 2,26 \\
\hline & 2008 & 2,21 & 1,23 & 0,1930 & 3,55 & 2,84 & 0,0090 & 1,79 & 3,49 & 0,0000 & 5040,6 & 0,0000 & $92 \%$ & 2,32 \\
\hline & 2009 & 1,53 & 1,45 & 0,0780 & $-7,24$ & $-1,12$ & 0,2710 & 4,88 & 6,19 & 0,0000 & 1851,9 & 0,0000 & $85 \%$ & 1,72 \\
\hline & 2010 & 1,12 & 1,98 & 0,1160 & 1,90 & 0,67 & 0,5060 & 2,73 & 5,19 & 0,0000 & 1351,1 & 0,0000 & $80 \%$ & 1,91 \\
\hline & 2011 & 2,64 & 1,74 & 0,0460 & 1,63 & 1,50 & 0,1440 & 2,18 & 10,87 & 0,0000 & 1013,9 & 0,0000 & $75 \%$ & 2,24 \\
\hline & 2012 & 1,41 & 0,97 & 0,3860 & 1,00 & 0,65 & 0,5210 & 2,01 & 10,43 & 0,0000 & 1492,0 & 0,0000 & $77 \%$ & 2,64 \\
\hline & $\mu$ Before & & & & & & & & & & & & $44,1 \%$ & \\
\hline & $\boldsymbol{\mu}$ After & & & & & & & & & & & & 81,8 & \\
\hline
\end{tabular}

Table 11. Model results In China (Not fully converged method - Not compliant)

\begin{tabular}{|c|c|c|c|c|c|c|c|c|c|c|c|c|c|c|}
\hline \multirow{2}{*}{ ن } & \multirow[b]{2}{*}{ Year } & \multicolumn{3}{|c|}{ Constant } & \multicolumn{3}{|c|}{ EPS } & \multicolumn{3}{|c|}{ BVS } & \multirow{2}{*}{$\mathbf{F}$} & \multirow{2}{*}{ Sig. F } & \multirow{2}{*}{ R2 } & \multirow{2}{*}{ D. W. } \\
\hline & & B0 & $t$ & Sig. & B1 & $t$ & Sig. & B2 & $t$ & Sig. & & & & \\
\hline \multirow{15}{*}{ 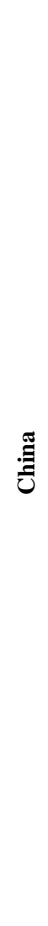 } & 2000 & 3,68 & 4,47 & 0,0000 & $-19,24$ & $-5,78$ & 0,0000 & 1,34 & 37,24 & 0,0000 & 2145,21 & 0,0000 & $88 \%$ & 2,00 \\
\hline & 2001 & 4,51 & 5,21 & 0,0000 & 10,04 & 6,94 & 0,0000 & 0,34 & 64,89 & 0,0000 & 5374,21 & 0,0000 & $92 \%$ & 2,01 \\
\hline & 2002 & 2,50 & 6,04 & 0,0000 & $-8,96$ & $-4,44$ & 0,0000 & 0,97 & 78,79 & 0,0000 & 5903,72 & 0,0000 & $94 \%$ & 1,98 \\
\hline & 2003 & 3,95 & 3,43 & 0,0001 & $-17,96$ & $-5,01$ & 0,0000 & 1,78 & 74,18 & 0,0000 & 5136,37 & 0,0000 & $91 \%$ & 2,00 \\
\hline & 2004 & 6,05 & 6,28 & 0,0000 & 1,01 & 4,95 & 0,0000 & 0,27 & 74,57 & 0,0000 & 5476,80 & 0,0000 & $93 \%$ & 2,02 \\
\hline & 2005 & 4,80 & 5,89 & 0,0000 & $-1,77$ & $-5,77$ & 0,0000 & 1,30 & 23,07 & 0,0000 & 5347,82 & 0,0000 & $92 \%$ & 2,02 \\
\hline & 2006 & 5,23 & 4,64 & 0,0000 & $-1,95$ & $-4,39$ & 0,0000 & 1,30 & 35,73 & 0,0000 & 1784,63 & 0,0000 & $81 \%$ & 2,01 \\
\hline & 2007 & 4,90 & 11,76 & 0,0000 & 2,50 & 9,22 & 0,0000 & 0,57 & 18,94 & 0,0000 & 278,80 & $\mathbf{0 , 0 0 0 0}$ & $53 \%$ & 1,87 \\
\hline & 2008 & 0,97 & 6,02 & 0,0000 & 1,46 & 21,96 & 0,0000 & 0,74 & 77,48 & 0,0000 & 5399,75 & $\mathbf{0 , 0 0 0 0}$ & $91 \%$ & 2,11 \\
\hline & 2009 & 2,29 & 10,50 & 0,0000 & 3,40 & 21,48 & 0,0000 & 0,68 & 42,83 & 0,0000 & 4275,89 & $\mathbf{0 , 0 0 0 0}$ & $83 \%$ & 1,67 \\
\hline & 2010 & 4,12 & 10,42 & 0,0000 & 0,51 & 1,30 & 0,0910 & $\mathbf{0 , 8 0}$ & 38,58 & 0,0000 & 1768,41 & $\mathbf{0 , 0 0 0 0}$ & $82 \%$ & 1,64 \\
\hline & 2011 & 3,15 & 6,66 & 0,0000 & 1,60 & 5,57 & 0,0000 & 0,69 & 21,01 & 0,0000 & 507,97 & $\mathbf{0 , 0 0 0 0}$ & $73 \%$ & 1,74 \\
\hline & 2012 & 5,12 & 12,51 & 0,0000 & 0,64 & 1,41 & 0,2145 & 0,97 & 26,54 & 0,0000 & 530,21 & $\mathbf{0 , 0 0 0 0}$ & $76 \%$ & 1,75 \\
\hline & $\mu$ Before & & & & & & & & & & & & $90,28 \%$ & \\
\hline & $\boldsymbol{\mu}$ After & & & & & & & & & & & & $76,33 \%$ & \\
\hline
\end{tabular}




\section{Summary and Discussion}

The Relevance is an essential characteristic of accounting information. Several researchers have studied this qualitative characteristic for the determination of the effect of an accounting referential on the quality of the accounting information. In terms of standards concerned by these studies, the IFRS have been widely studied. Thus, to accomplish this objective, several models have been developed. The comparison of results of these models shows a better explanatory power of model of Ohlson (1995) and a large difference in the results from one country to another. This difference in results may be caused by several factors. The study of Zeef and Nobes (2010) on the methods of implementation of IFRS has conducted us to think that the compliance of methods of implementation of IFRS with the IFRS issued by the IASB influences the relevance of accounting information. Thus, through this study we have tried to investigate the effect of the compliance of methods of implementation of IFRS on the relevance of accounting information.

We have used the Ohlson model to study this effect. Also, we have used the classification made by Zeff and Nobes (2010). According these authors, the implementation of IFRS for the listed companies around the world can be decomposed according to its degree of implementation and compliance with IFRS issued by the IASB into four methods of implementation: the first method is the "due process" which is the most advanced degree of implementation; the second method is the "standard by standard" implementation; it includes three levels named "adoption of the publications of the IASB", "full IFRS convergence" and "IFRS adoption and deletions". The third implementation method is the "optional" adoption and the last method is the "incomplete convergence".

Subsequently, two models have been used. The first model aims to study the effect of the compliance of methods of implementation on the relevance of accounting information and the second model is proposed to compare the relevance between the countries of the sample adopting different methods of implementation of IFRS. The period chosen is of 3 years (2010-2013) for the first model and of 13 years (2000-2012) for the second model. The number of countries is six. These countries have implemented the IFRS by various methods of implementation.

The results show a significant effect of the compliance of the method of implementation of IFRS on the relevance of the accounting information. This effect is positive which demonstrates that the compliance is positively correlated with the relevance. Also, the results demonstrate an improvement of the relevance in countries as Israel which has opted for a "due process" method, Honk Kong which has selected a "complete convergence" method, the United Kingdom which has adopted the method "IFRS with deletions" and Switzerland which has selected an "optional” method for the implementation of IFRS. In Canada a country which has opted for a method of implementation "IFRS as issued by the IASB", the results demonstrate a maintain of the high relevance of accounting information for the period after the transition to IFRS. In china, a decline of the relevance of accounting information is observed following the adoption of the new Chinese accounting standards which are fairly close but not fully compliant with the IFRS. 
These results confirm those of some studies on the relevance of accounting information which demonstrate an improvement of the relevance following the adoption of IFRS such as the studies of Bartov et al. (2005) and of Morais and Curto (2009). The first authors have reported a greater relevance of U.S. GAAP and IAS compared to German standards. The second have noticed through a sample of companies listed in 14 European countries that the relevance of the value of financial statements of these countries had increased following their transition to IFRS.

\section{References}

Amir, E., and Harris, T.S., \& Venuti E.K. (1993). A comparison of value relevance of US versus non-USGAAP accounting measures using Form 20-F reconciliations, Journal of Accounting Research Supplement, 31, 230-264. http://dx.doi.org/10.2307/2491172

Amir, E., Harris, T.S., \& Venuti, E.K. (1993). A comparison of value relevance of US versus non-US-GAAP accounting measures using Form 20-F reconciliations, Journal of Accounting Research Supplement, 31, 230-264. http://dx.doi.org/10.2307/2491172

Amir, E., \& Lev, B. (1996). Value relevance of nonfinancial information: The wireless communications industry. Journal of Accounting and Economics, 22, 3-30. http://dx.doi.org/10.1016/S0165-4101(96)00430-2

Amir, E. (1996). The effect of accounting aggregation on the value relevance of financial disclosures: The case of SFAS. Accounting Review, 106, 573-590.

Amir, E. (1996). The market valuation of accounting information: The case of postretirement benefits other than pensions. Accounting Review, 68, 703-724.

Ashbaugh, H., \& M., Pincus. (2001). Domestic Accounting Standards, International Accounting Standards, and the Predictability of Earnings. Journal of Accounting Research, 39, 417-434. http://dx.doi.org/10.1111/1475-679X.00020

Auer, K. (1996). Capital market reactions to earnings announcements: empirical evidence on the difference in the information content of IAS-based earnings and EC-Directives-based earnings. The European Accounting Review, 5-4, 587- 623.

Bao, B., \& Chow, L. (1999). The usefulness of earnings and book value for equity valuation in emerging capital markets: evidence from listed companies in the People's Republic of China. Journal of International Financial Management and Accounting, 10(2), 85-103. http://dx.doi.org/10.1111/1467-646X.00045

Barth, M.E., \& Clinch, G. (1996). International accounting differences and their relation to share prices: Evidence from U.K., Australian, and Canadian firms. Contemporary Accounting Research, 13, 135-170. http://dx.doi.org/10.1111/j.1911-3846.1996.tb00495.x

Bartov, E., Goldberg, S.R., \& Kim, M.S. (2002). Comparative Value Relevance among German, U.S. and International Accounting Standards: a German Stock Market Perspective, working paper, New York University, Grand Valley State University. University of Missouri-Columbia. 
Bartov, E., Goldberg, S., \& Kim, M. (2005). Comparative value relevance among German, U.S., and international accounting standards: A German stock market perspective. Journal of Accounting, Auditing and Finance, 20(2), 95-119.

Beckman, J, Brandes, C, \& Eierle B. (2007). German reporting practices: an analysis of reconciliations from German commercial code to IFRS or US GAAP. Advances in International Accounting, 20, 253-94. http://dx.doi.org/10.1016/S0897-3660(07)20009-1

Burlaud, A., \& Colasse, B. (2010). Normalisation comptable internationale : le retour du politique ?, Comptabilité-Contrôle-Audit, 16(3), 153-175.

Chalmers, K, Clinch, G., \& Godfrey, J.M. (2008). Adoption of international financial reporting standards impact on the value relevance of intangible assets, Australian Accounting Review, 18, 237-247. http://dx.doi.org/10.1111/j.1835-2561.2008.0028.x

Chalmers, K., Clinch G., \& Godfrey J. (2011). Changes in value relevance of accounting information upon IFRS adoption: Evidence from Australia, Australian Journal of Management, 36, 151-173. http://dx.doi.org/10.1177/0312896211404571

Chalmers, K., Clinch, G., Godfrey, J.M, \& Zi W. (2011). Intangible Assets, IFRS and Analysts Earnings Forecasts, Accounting and Finance.

Chen, H., \& Sami, H. (2008). Trading Volume Reaction to the Earnings Reconciliation from IAS to U.S. GAAP, Contemporary Accounting Research, 25(1), 15-53.

Eccher, E., \& Healy, P. (2000). The Role of International Accounting Standards in Transitional Economies: A study of the People's Republic of China, Working Paper Series, Massachusetts Institute of Technology..

Godfrey, J.M., \& Chalmers, K. (2008). Globalization of Accounting Standards: An Introduction. Globalisation of Accounting Standards, Northampton. MA: Edward Edgar Publishing, 1-14.

Harris, M.S., \& Muller, K.A. (1999). The market valuation of IAS versus US-GAAP accounting measures using Form 20-F reconciliations. Journal of Accounting and Economics, 26, 285-312. http://dx.doi.org/10.1016/S0165-4101(99)00003-8

Horton, J., \& Serafeim, G. (2009). Market reaction to and valuation of IFRS reconciliation adjustments: first evidence from the UK, Review of Accounting Studie.

Hung, M., \& Subramanyam, K.R. (2007). Financial Statement Effects of the Adoption of International Accounting Standards: The Case of Germany. Review of Accounting Studies, 12(4), 623-657. http://dx.doi.org/10.1007/s11142-007-9049-9

Jermakowicz, E., Prather-Kinsey. J., \& Wulf, I. (2007). The Value Relevance of Accounting Income Reported by DAX-30 German Companies. Journal of International Financial Management and Accounting, 18(3). http://dx.doi.org/10.1111/j.1467-646X.2007.01011.x 


\section{Macrothink}

Asian Journal of Finance \& Accounting ISSN 1946-052X 2014, Vol. 6, No. 2

Morais I.A, \& Curto J.D. (2009). Mandatory Adoption of IASB Standards: Value Relevance and Country-Specific Factors. Australian Accounting Review, 19(2), 128-143.

Nobes, C. (2008). Accounting Classification in the IFRS Era. Australian Accounting Review, 18(3),191-198.

Ohlson, J.A. (1995). Earnings, Book Values, and Dividends in Equity Valuation, Contemporary Accounting Research, 661-687. http://dx.doi.org/10.1111/j.1911-3846.1995.tb00461.x

Pope, P.F., \& Rees, W. (1993). International differences in GAAP and the pricing of earnings, Journal of International Financial Management and Accounting, 4, 190-219. http://dx.doi.org/10.1111/j.1467-646X.1992.tb00029.x

Zeff, S.A, \& Nobes, C.W. (2010). Commentary: Has Australia (or Any Other Jurisdiction) 'Adopted' IFRS?, Australian Accounting Review, 20(2), 178-184. http://dx.doi.org/10.1111/j.1835-2561.2010.00089.x 